\title{
ANALISIS WEBSITE QUALITY, TRUST DAN LOYALTY PELANGGAN ONLINE SHOP
}

\author{
Hotlan Siagian $^{1 *}$; Edwin Cahyono ${ }^{2}$ \\ ${ }^{1}$ Fakultas Ekonomi Universitas Kristen Petra \\ Jl. Siwalankerto 121-131, Surabaya 60236 \\ ${ }^{2}$ Praktisi Marketing \\ Email: hotlan.siagian@petra.ac.id; edwinsing@ymail.com \\ Korespondensi penulis
}

\begin{abstract}
Abstrak: Fenomena penggunaan toko online (online shop) sebagai media transaksi pembelian barang maupun jasa meningkat pesat di Indonesia. Jumlah pemilik toko online juga meningkat tajam sehingga persaingan tidak bisa dihindarkan. Kualitas situs web (website quality) merupakan salah satu faktor yang dapat menimbulkan kepercayaan (trust) dan selanjutnya akan menghasilkan loyalitas (loyalty) pelanggan online shop. Penelitian ini bertujuan menganalisis pengaruh website quality terhadap trust dan pengaruh trust terhadap loyalty pelanggan online shop di wilayah Jawa Timur. Pengumpulan data dilakukan melalui penyebaran kuisioner secara online dan offline di lingkungan Universitas Kristen Petra Surabaya. Data sebanyak 249 responden digunakan sebagai sampel penelitian ini dan di analisis menggunakan program SPSS for Windows Version 16 dan SmartPLS Version 1.01. Hasil analisa data menunjukkan bahwa website quality berpengaruh terhadap trust, dan trust berpengaruh terhadap loyalty pelanggan online shop.
\end{abstract}

Kata kunci: Website quality, trust, loyalty, online shop.

\begin{abstract}
The use of online store as purchasing media of goods and services increased rapidly in Indonesia. The number of online store owners also rose sharply such that competition unavoidable. Website quality is one of the factors that influece trust and trust will generate loyalty of the online shop customer. This research aimed to analyze the influence of website quality on trust and the influence trust on customer loyalty in East Java area. The research was conducted by distributing questionnaires to 249 respondens which selected randamly at Petra Christian University campuss. Data was analyzed using SPSS for Windows Version 16 and SmartPLS Version 1.01. The results obtained, website quality influence trust, and trust influence customer loyalty.
\end{abstract}

Keywords: Webiste quality, trust, loyalty, online shop.

\section{PENDAHULUAN}

Transaksi online merupakan salah satu aplikasi kemajuan teknologi informasi yang penggunaannya sangat intens akhir-akhir ini. Pada awal munculnya, orang tidak begitu yakin melakukan transaksi online karena dalam transaksi online, seseorang sepenuhnya bergantung pada kepercayaan atas informasi yang disampaikan pemilik dalam website tersebut dan pengunjung website tidak bisa melihat secara kasat mata tentang produk yang ditawarkan (Buttner \& Goritz, 2008). Namun pada kenyataannya transaksi online terus meningkat dengan pesat. Jumlah pembeli online di Indonesia dari tahun ke tahun terus meningkat, demikian juga jumlah toko online (online shop) di berbagai media online meningkat tajam. Peluang toko online semakin terbuka luas namun persaingan juga semakin intensif. Pemilik toko online harus mengetahui dan memenuhi keinginan pelanggan agar percaya dan menjadi pelanggan yang loyal. Tantangan tersebut tentu tidaklah mudah, ibarat toko yang bersaing mendapatkan pelanggan dari orang- orang yang berkunjung. Demikian juga toko online akan dikunjungi oleh calon pelanggan pengguna media online kapan dimanapun mereka berada. Pemilik toko online harus memberikan pelayanan terbaik mereka dengan cara memperhatikan kualitas situs web (website quality) untuk meyakinkan pengunjung dan mendapatkan kepercayaan (trust) dan selanjutnya menimbulkan loyalitas (loyality) pelanggan (Sadeh et al. 2011).

Faktor kepercayaan (trust) merupakan faktor kunci dari sekian banyak faktor yang mempengaruhi terjadinya transaksi jual beli pada toko online (online shop). Hanya pelanggan yang memiliki kepercayaan (trust) yang akan berani melakukan transaksi melalui media internet. Tanpa ada kepercayaan dari pelanggan, mustahil transaksi melalui media internet akan terjadi (Gustavsson \& Johansson 2006). Beberapa penelitian tentang hubungan kualitas layanan dengan kepercayaan pelanggan, antara lain penelitian yang berjudul "A Model of the Relationship among Consumer Trust, Web Design and User Attributes" yang dilakukan oleh Zhang (2009) menemu- 
kan bahwa melakukan transaksi secara online termasuk cara yang mudah dan canggih, akan tetapi kepercayaan konsumen kepada perusahaan sangat rentan dan susah untuk didapatkan. Penelitian ini menjelaskan bahwa kualitas sebuah website dapat meningkatkan kepercayaan konsumen yang melakukan transaksi secara online, karena konsumen yang bertransaksi secara online hanya mengandalkan informasi yang di dapat dari website yang menjual produk atau jasa tersebut.

Pratiwi (2012) dalam penelitiannya yang berjudul "Pengaruh Reputasi Perusahaan Dan Kualitas Website Terhadap Tingkat Kepercayaan Konsumen Dalam Bertransaksi Secara Online (Studi pada Konsumen Ongisnadestore.com)" mengemukakan bahwa terdapat pengaruh signifikan antara reputasi perusahaan dan kualitas website secara simultan atau bersamasama pada tingkat kepercayaan konsumen dalam bertransaksi secara online. Penelitian lainnya terhadap situs lelang online yaitu e-bay telah dilakukan oleh Gregg \& Walczak (2010) yang berjudul "The relationship between website quality, trust and price premiums at online auctions". Penelitian tersebut mengemukakan bahwa penjual dengan kualitas website yang baik, meskipun tidak memiliki reputasi yang bagus, lebih dipercaya dibanding penjual dengan reputasi yang bagus, tetapi kualitas website tidak bagus.

Berdasarkan teori dan beberapa hasil penelitian menyatakan bahwa kualitas pelayanan berdampak pada loyalitas pelanggan, akan tetapi penelitian yang dilakukan Munusamy et al. (2010) menunjukkan bahwa kualitas pelayanan tidak berpengaruh pada loyalitas pelanggan. Penelitian ini dilakukan terhadap online banking dimana sebagian responden terbiasa berhadapan dengan manusia. Ketika melakukan transaksi melalui automatic teller machine (ATM) atau peralatan elektronik lainnya kemungkinan mengalami kekecewaan karena adanya gangguan saat bertransaksi. Kheng (2010) juga mengemukakan bahwa beberapa dimensi dari kualitas layanan seperti tangibles dan responsiveness tidak memiliki dampak yang signifikan terhadap kepuasan dan loyalitas pelanggan. Hal ini dikarenakan, responden pada penelitian tersebut merasa bahwa sistem teknologi informasi yang canggih lebih penting daripada kemewahan interior dari sebuah bank. Penelitian tersebut dilakukan pada objek industri software komputer dimana responden merasa puas dengan kualitas dari software komputer yang digunakan, namun sebagian besar mereka enggan melakukan pembelian kembali karena beberapa kemungkinan yaitu harga software tersebut cukup mahal dan penggunaan software tersebut membutuhkan spesifikasi komputer yang canggih. Sehingga konsistensi hasil dari dampak kualitas pelayanan dalam online shop merupakan kualitas situs web (website quality) terhadap loyalitas (loyalty) masih kurang.

Berdasarkan fakta-fakta di atas, maka penelitian tentang analisis pengaruh kualitas situs web (website quality) terhadap kepercayaan (trust) dan pengaruh kepercayaan (trust) terhadap loyalitas (loyalty) pada pelanggan online shop masih perlu dilakukan.

\section{LANDASAN TEORI DAN HIPOTESIS}

\section{Perilaku Konsumen}

Perilaku konsumen adalah bidang studi yang relatif baru dari pertengahan hingga akhir tahun 1960an. Karena bidang studi perilaku konsumen tidak memiliki sejarah tentang penelitiannya sendiri, teoriteori manajemen pemasaran meminjam pengembangan konsep perilaku konsumen tersebut dari beberapa disiplin ilmu yang lain, seperti psikologi yang mempelajari tentang individu, sosiologi yang mempelajari tentang sekelompok orang/masyarakat, sosial psikologi yang mempelajari tentang bagaimana seorang individu bertindak dalam sebuah kelompok, antropologi yang mempelajari tentang dampak dari adanya sebuah masyarakat kepada seorang individu, dan ekonomi untuk membentuk dasar disiplin ilmu pemasaran yang baru.

Perilaku konsumen berfokus kepada bagaimana seseorang individu mengambil keputusan untuk menghabiskan sumber daya yang mereka punya (waktu, uang, dan usaha) dalam mengkonsumsi barang maupun jasa yang berkaitan (Schiffman \& Kanuk 2004).

\section{Kualitas situs web (Website quality)}

Website Quality merupakan salah satu konsep yang digunakan dalam pengukuran kualitas website berdasarkan persepsi pengguna akhir. Konsep ini merupakan pengembangan dari SERVQUAL yang banyak digunakan sebelumnya pada pengukuran kualitas jasa. Website Quality atau yang biasa disebut WebQual sudah mulai dikembangkan sejak tahun 1998 dan telah mengalami beberapa iterasi dalam penyusunan dimensi dan butir-butir pertanyaannya. Website Quality disusun berdasarkan penelitian pada tiga area (Sumarwan 2007), yaitu: kualitas informasi dari penelitian sistem informasi, interaksi dan kualitas layanan dari penelitian sistem informasi, e-commerce, serta pemasaran, dan kegunaan (usability) dari human-computer interaction. 


\section{Kepercayaan (Trust)}

Kepercayaan (Trust) merupakan keyakinan satu pihak mengenai maksud dan perilaku pihak yang lainnya. Dengan demikian kepercayaan konsumen didefinisikan sebagai harapan konsumen bahwa penyedia jasa dapat dipercaya atau diandalkan dalam memenuhi janjinya. Ganesan (1994) menyebut kepercayaan sebagai kredibilitas. Dalam penelitiannya Ganesan (1994) mengartikan kredibilitas sebagai sejauh mana pembeli percaya bahwa pemasok memiliki keahlian untuk melakukan aktivitas secara efektif dan andal. Menurut Ganesan (1994) kepercayaan berhubungan dengan niat perusahaan untuk mengandalkan mitra pertukaran mereka. Ganesan (1994) menjelaskan bahwa kepercayaan sebagai sebuah kebajikan, karena didasarkan pada sejauh mana perusahaan percaya bahwa mitranya memiliki niat dan motif-motif yang menguntungkan.

\section{Loyalitas Pelanggan (Customer Loyalty)}

Loyalitas pelanggan adalah salah satu hasil yang paling penting dari sebuah bisnis online. Diperdebatkan, loyalitas memberikan indikator keberhasilan yang berarti untuk sebuah organisasi dalam lingkungan pasar yang kompetitif. Loyalitas konsumen menurut Hur et al. (2013) didefinisikan sebagai "komitmen yang dipegang teguh untuk membeli kembali produk pilihan atau jasa secara konsisten di masa mendatang, sehingga menyebabkan pembelian berulang produk atau jasa dengan merek yang sama, meskipun ada pengaruh situasional dan upaya pemasaran yang memiliki potensi untuk menyebabkan perilaku beralih ke produk atau jasa dengan merek yang lain".

Gommans et al. (2001) loyalitas didasari oleh proposisi nilai, brand building, kepercayaan dan kemanan, website dan teknologi, dan layanan pelanggan. Di dalam konteks e-commerce, kepuasandan kepercayaan pelanggan berdampak pada loyalitas pelanggan. Oleh karena itu dapat disimpulkan bahwa pelanggan yang loyal adalah pelanggan yang memiliki kepercayaan kepada online shop dan membeli secara berulang serta berkomitmen terhadap produk yang ditawarkan walau telah dihadapkan pada beberapa pilihan produk pesaing. Selain itu, pelanggan yang loyal akan mereferensikan produk kepada lingkungan sekitarnya.

\section{Hipotesis Penelitian}

Melakukan transaksi secara online termasuk cara yang mudah dan canggih, akan tetapi kepercayaan konsumen kepada perusahaan sangat rentan dan susah untuk didapatkan (Zhang 2009). Kualitas sebuah situs web dapat meningkatkan kepercayaan konsumen yang melakukan transaksi secara online (Pratiwi 2012). Terdapat pengaruh positif antara reputasi perusahaan dan kualitas website secara simultan atau bersama-sama pada tingkat kepercayaan konsumen dalam bertransaksi secara online. Penjual yang memiliki kualitas website yang bagus, meskipun mereka tidak memiliki reputasi yang bagus, tetap lebih dipercaya (Gregg \& Walczak 2010) daripada penjual yang memiliki reputasi yang bagus, tetapi kualitas website jelek. Penjelasan tersebut diatas menghasilkan Hipotesis

H1: Website Quality berpengaruh terhadap Trust pelanggan online shop.

Minat beli yang merupakan salah satu bentuk dari loyalitas pelanggan ditentukan oleh trust (Buttner \& Goritz 2008). Trust pelanggan online shop menentukan minat beli yang merupakan salah satu bentuk dari loyalitas pelanggan (Gustavsson \& Johansson 2006). Banyak orang yang tidak melakukan pembelian karena adanya rasa kurang percaya sehingga membangun kepercayaan dari pelanggan merupakan tantangan dari pemilik online shop. Trust memiliki hubungan yang langsung dengan loyalty. Berdasarkan uraian tersebut, maka hipotesis dalam penelitian ini adalah:

H2: Trust berpengaruh terhadap Loyalty pelanggan online shop.

\section{Model Penelitian}

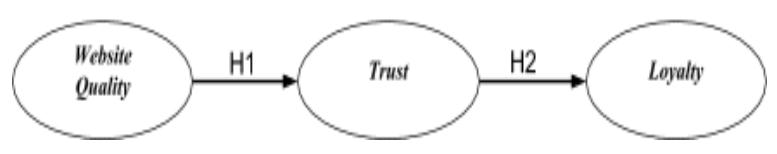

Gambar 1. Model Penelitian

\section{METODE PENELITIAN}

Dalam suatu penelitian, dibutuhkan suatu metode yang digunakan untuk mencapai tujuan penelitian yang telah ditentukan. Metode penelitian merupakan suatu cara yang ditempuh dalam mengumpulkan, menganalisa serta menginterpretasikan data. Metode penelitian yang digunakan dalam penelitian ini adalah metode penelitian kuantitatif. Penelitian kuantitatif diartikan sebagai metode penelitian berdasarkan filsafat positivisme yang digunakan untuk meneliti populasi atau sampel tertentu. Pengumpulan data menggunakan instrumen penelitian dan analisis data bersifat kuantitatif yang bertujuan menguji hipotesis yang telah ditetapkan. 
Penelitian kuantitatif ini bertujuan mengungkapkan hubungan sebab-akibat antar variabel yang digolongkan sebagai jenis penelitian kausal. Penelitian kausal, selain mengukur kekuatan hubungan antara dua variabel atau lebih, juga menunjukkan arah hubungan antara variabel bebas dan terikat.

\section{Populasi \& Sampel}

Populasi adalah kelompok elemen yang lengkap yang biasanya berupa orang, objek, transaksi, atau kejadian dimana kita tertarik untuk mempelajarinya atau menjadikan objek penelitian. Populasi (population) mengacu pada keseluruhan kelompok orang, kejadian, atau hal minat yang ingin peneliti investigasi (Sekaran 2006). Sampel (sample) adalah sebagian dari populasi (Sekaran 2006). Sampel terdiri atas sejumlah anggota yang dipilih dari populasi. Dalam penelitian ini penulis menggunakan teknik non-probability sampling dan purposive sampling. Non-probability sampling adalah teknik pengambilan sampel yang tidak memberi peluang atau kesempatan yang sama bagi setiap unsur atau anggota populasi untuk dipilih menjadi sampel. Purposive sampling merupakan teknik penentuan sampel dengan pertimbangan tertentu (Sekaran 2006).

Jumlah sampel yang penulis tentukan menggunakan teori yang dikembangkan oleh Isaac dan Michael, yaitu untuk penentuan jumlah sampel dan populasi yang tidak terbatas dengan tingkat kesalahan 5\% adalah 249 sampel (Sekaran 2006), dibulatkan menjadi 250 sampel sebagai tindakan untuk mengantisipasi adanya kesalahan responden dalam pengisian kuisioner dan mempermudah pembagian jumlah kuisioner untuk setiap lokasi penyebaran kuisioner.

\section{Metode Pengumpulan Data}

Metode pengumpulan data merupakan bagian integral dari desain penelitian. Ada beberapa metode pengumpulan data, masing-masing dengan kelebihan dan kekurangannya. Masalah yang diteliti dengan penggunaan metode yang tepat sangat meningkatkan nilai penelitian. Mewawancara, memberikan kuesioner, dan mengobservasi orang dan fenomena adalah tiga metode pengumpulan data yang utama dalam penelitian survei (Sekaran 2006). Pilihan metode pengumpulan data tergantung pada fasilitas yang tersedia, tingkat akurasi yang disyaratkan, keahlian peneliti, kisaran waktu studi, biaya, dan sumber daya lain yang berkaitan dan tersedia untuk pengumpulan data. Metode pengumpulan data dalam penelitian ini adalah penyebaran kuesioner secara langsung. Kuesioner (questionnaires) adalah daftar pertanyaan ter- tulis yang telah dirumuskan sebelumnya yang akan responden jawab, biasanya dalam alternatif yang didefinisikan dengan jelas. Kuesioner merupakan suatu mekanisme pengumpulan data yang efisien jika peneliti mengetahui dengan tepat apa yang diperlukan dan bagaimana mengukur variabel penelitian. Kuesioner dapat diberikan secara pribadi, disuratkan kepada responden, atau disebarkan secara elektronik.

Analisis yang digunakan untuk menguji hipotesis penelitian ini menggunakan Partial Least Square (PLS) dengan program aplikasi software Smart PLS. Pemilihan alat analisis ini karena kesesuaian software dengan kebutuhan pengolahan data dari model yang memiliki hubungan variabel secara simultan.

\section{HASIL PENELITIAN DAN PEMBAHASAN}

\section{Analisa Deskriptif}

Usia 19-24 tahun merupakan responden dengan jumlah paling banyak yaitu sebesar 102 (41\%). Responden usia ini memiliki kecenderungan aktif untuk mencoba berbagai hal baru termasuk pembelian secara online. Pengalaman-pengalaman yang didapatkan dinilai bisa memenuhi kebutuhan rasa ingin tahu terhadap berbagai hal baru. Selain itu, identitas sosial sebagai kelompok moderen juga bisa mendorong responden kelompok usia paling muda ini sehingga terkesan lebih banyak aktif dan tertarik dalam transaksi di online shop. Jumlah terbanyak kedua adalah responden usia antara 30-34 tahun sebanyak 60 responden (24\%). Responden usia ini adalah responden yang sudah bekerja sehingga kelompok usia ini memiliki keberanian untuk menanggung risiko dari transaksi online karena menilai dirinya sudah berpenghasilan. Responden terbanyak ketiga adalah responden usia antara 25-29 tahun yaitu sebanyak 45 responden (18\%).

Jumlah responden jenis kelamin laki-laki maupun perempuan dengan jumlah yang relatif sama. Perbandingannya antara $47 \%$ perempuan dan $53 \%$ laki-laki. Jumlah yang relatif sama ini mempresentasikan bahwa kunjungan terhadap online shop untuk berbelanja atau membeli produk tertentu bisa diakses oleh laki-laki maupun perempuan. Terdapat berbagai pertimbangan yang mendorong responden perempuan melakukan pembelian di online shop diantaranya adalah banyaknya pilihan di berbagai online shop, kemungkinan harga lebih rendah karena tanpa perantara juga bisa menjadi alasan bagi responden perempuan tertarik melakukan pembelian secara online. Untuk responden laki-laki bisa lebih terdorong efisiensi dari waktu dan efektifitas dari proses pembelian yang didapatkan dari online shop sehingga tertarik melakukan pembelian. 
Berdasarkan pada frekuensi pembelian dalam 1 tahun terakhir, sebanyak 88 responden $(35 \%)$ menyatakan telah melakukan pembelian sebanyak 3 kali. Sebanyak 60 responden (24\%) menyatakan telah melakukan pembelian sebanyak 2 kali, dan 57 responden (23\%) menyatakan telah melakukan pembelian sebanyak 4 kali. Berdasarkan frekuensi pembelian, sebagian besar responden penelitian ini bisa dinyatakan cukup pengalaman dalam melakukan pembelian di online shop.

Terdapat beragam online shop yang bisa dikunjungi oleh responden. Data dari 250 responden penelitian, terdapat 25 online shop yang paling sering digunakan untuk melakukan pembelian. Apple Store adalah online shop yang paling banyak menjadi tempat pembelian responden yaitu sebanyak 22 responden (9\%). berniaga.com, bhinneka.com dan Disctarra adalah online shop kedua yang paling banyak menjadi tempat pembelian oleh konsumen. Berdasarkan pada pilihan online shop, popularitas online shop terlihat juga menjadi pertimbangan bagi konsumen untuk melakukan pembelian.

\section{Outer dan Inner Model}

Outer model menjelaskan hubungan antara indikator dan variabel sedangkan inner model menjelaskan hubungan antar variabel penelitian. Outer dan inner model sebagaimana ditunjukkan Gambar 2.

Gambar 2 menunjukkan setiap indikator memiliki loading factor yang cukup tinggi dan hanya satu indikator dari Website Quality dengan nilai loading sebesar 0,677.Temuan ini menunjukkan bahwa outer model dari penelitian ini dinilai cukup representatif. Demikian halnya dengan inner model, diketahui bahwa terdapat pengaruh dari Website Quality terhadap Trust. Demikian halnya dengan variabel Trust memiliki pengaruh terhadap Loyalty.
Pada variabel Website Quality, nilai loading terbesar terdapat pada kemudahan penggunaan website, seperti kemudahan mengakses, kemudahan pengoperasian dan pada keamanan dalam bertransaksi, seperti terdapat contact person yang bisa dihubungi. Sebagian besar pelanggan online shop merasakan adanya kemudahan dalam mengakses website dan pengoperasian website dan juga mereka merasa aman dalam bertransaksi secara online karena adanya contact person yang bisa dihubungi.

Pada variabel Trust, nilai loading terbesar terdapat pada konsistensi yang diberikan online shop kepada pelanggan. Hal ini berarti pelanggan percaya akan konsistensi yang diberikan oleh pemilik online shop terhadap mereka, seperti contoh dengan adanya kualitas barang yang sesuai tertera pada website, tepatnya waktu pengiriman barang ke tangan pelanggan, dan sebagainya sehingga kepercayaan mereka berdampak pada loyalitas yang terbukti dengan pembelian atau pengunjungan kembali ke online shop tersebut.

Pada variabel Loyalty, nilai loading factor terbesar terdapat pada pemberian rekomendasi dari pelanggan kepada teman dan saudara mereka. Pelanggan online shop yang telah merasakan puas dan percaya terhadap suatu online shop, akan memberikan rekomendasi kepada teman dan saudara mereka untuk mengunjungi atau melakukan transaksi di online shop tersebut.

Sesuai dengan inner model yang bisa dilihat di Gambar 2, pada konteks berbelanja secara online, kepercayaan pelanggan ditentukan oleh kualitas website. Dari kepercayaan pelanggan akan mengakibatkan loyalitas pelanggan. Dari kualitas website tersebut, pelanggan percaya akan misalnya saja informasi produk yang sangat jelas, sistem keamanan dalam melakukan transaksi yang tinggi, terdapat contact person yang jelas, yang mengakibatkan orang

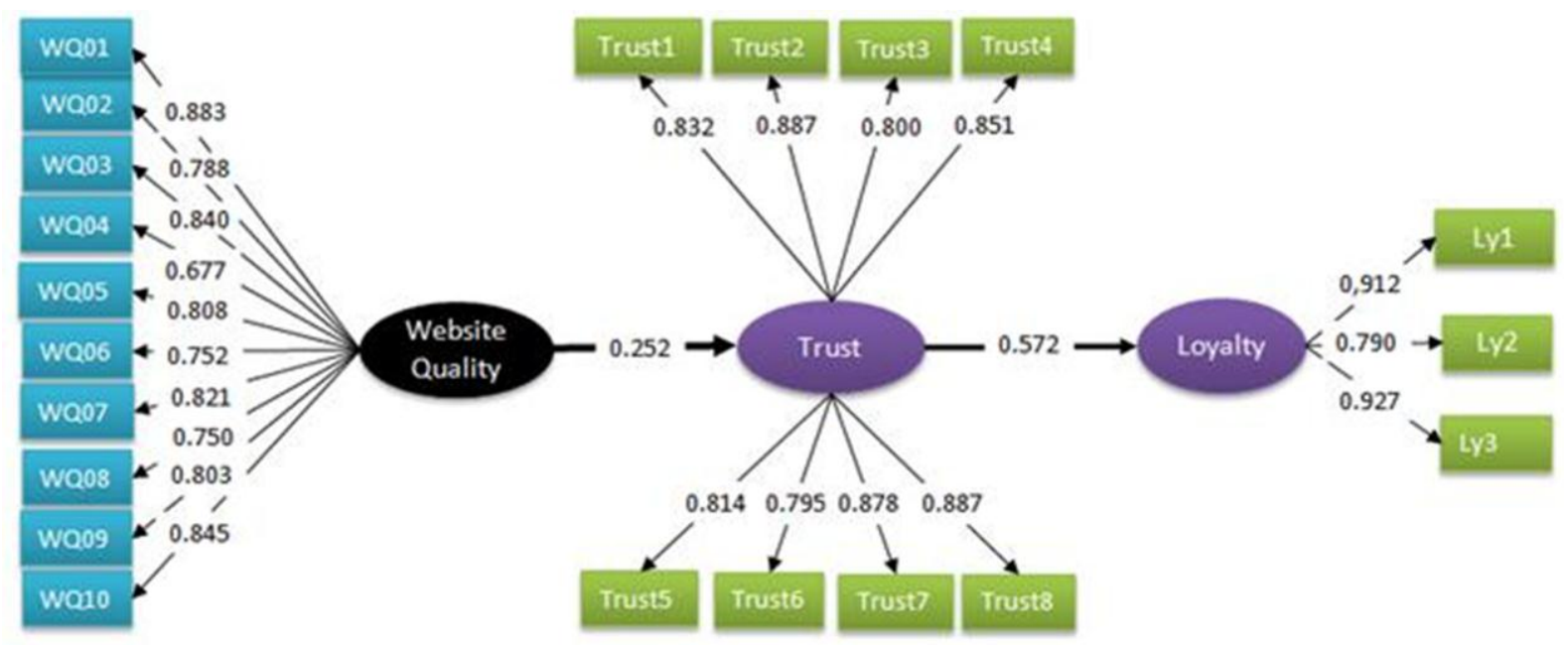

Gambar 2. Outer Model dan Inner Model 
tidak ragu untuk berbelanja pada online shop tersebut. Dengan kepercayaan tersebut pengunjung akan melakukan transaksi. Kepercayaan pelanggan pada akhirnya akan menimbulkan loyalitas. Salah satu contoh bentuknya adalah dengan melakukan pembelian atau kunjungan ulang dan memberikan rekomendasi kepada teman maupun saudara.

Tabel 1. R-Square

\begin{tabular}{lc}
\hline \multicolumn{1}{c}{ Variabel } & R-square \\
\hline Website Quality & 0 \\
Trust & 0,804 \\
Loyalty & 0,833 \\
\hline
\end{tabular}

Nilai $R$-Square untuk variabel Trust adalah sebesar 0,804 yang memiliki arti bahwa prosentase besarnya Trust yang bisa dijelaskan oleh Website Quality adalah sebesar $80,4 \%$. Nilai $R$-Square untuk variabel Loyalty adalah sebesar 0,833 yang memiliki arti bahwa prosentase besarnya Loyalty yang bisa dijelaskan Trust adalah sebesar 83,3\%.

Pada model PLS, penilaian goodness of fit diketahui dari nilai $\mathrm{Q}^{2}$. Dari Tabel 1 dapat dihitung nilai $\mathrm{Q}^{2}$ sebagai berikut:

$$
\begin{aligned}
\mathrm{Q}^{2} & =1-\left(1-\mathrm{R} 1^{2}\right)\left(1-\mathrm{R} 2^{2}\right) \\
& =1-(1-0,804)(1-0,833) \\
& =0,97
\end{aligned}
$$

Dari hasil perhitungan diketahui nilai $\mathrm{Q}^{2}$ sebesar 0,97 . Nilai $\mathbf{Q}^{2}>0$, artinya bahwa model penelitian dalam penelitian ini memiliki predictive relevance, sehingga layak untuk dilakukan analisa lebih lanjut.

\section{Pengujian Hipotesis Penelitian}

Pengujian hipotesis penelitian ini untuk membuktikan pengaruh setiap variabel independen yaitu website quality terhadap variabel dependen yaitu Trust dan Loyalty. Pengujian didasarkan pada nilai tvalue dengan ketentuan bahwa jika nilai $\mathrm{t}$-value $>1,960$ maka pengaruh variabel tersebut terhadap variabel yang lain dinyatakan signifikan. Tabel 2 menunjukkan hasil pengujian hipotesis penelitian.

Tabel 2. Pengujian Inner Model

\begin{tabular}{lcccc}
\hline \multicolumn{1}{c}{ Hipotesis } & $\begin{array}{c}\text { Original } \\
\text { sample } \\
\text { estimate }\end{array}$ & $\begin{array}{c}\text { Standard } \\
\text { deviation }\end{array}$ & & \\
\hline $\begin{array}{l}\text { Pengaruh Website } \\
\text { Quality terhadap }\end{array}$ & 0,252 & 0,06 & 4,51 & Terbukti \\
$\begin{array}{l}\text { Trust } \\
\text { Pengaruh Trust } \\
\text { terhadap Loyalty }\end{array}$ & 0,572 & 0,08 & 7,10 & Terbukti \\
\hline
\end{tabular}

Pengujian pertama menunjukkan bahwa Website Quality terbukti berpengaruh terhadap Trust. Nilai $\mathrm{t}_{\text {value }}$ sebesar 4,51 menunjukkan bahwa pengaruh Website Quality terhadap Trust adalah signifikan. Hal ini berarti k Website Quality memiliki pengaruh terhadap Trust dari pelanggan. Website Quality difungsikan sama sebagai toko offline, sehingga kunjungan konsumen ke website tidak ubahnya seperti kunjungan konsumen ke toko offline. Untuk itu, desain yang menarik, berbagai informasi yang bermanfaat, dan berbagai atribut lain terkait dengan Website Quality menunjukkan kompetensi dari online shop untuk bisa memberikan layanan terbaik bagi konsumen.

Pengujian kedua adalah pengujian untuk membuktikan pengaruh Trust terhadap Loyalty. Trust terbukti secara signifikan mempengaruhi Loyalty dengan nilai $\mathrm{t}_{\text {value }}$ sebesar 7,10. Hal ini dapat dimaknai bahwa semakin tinggi kepercayaan konsumen terhadap online shop maka loyalitas akan semakin tinggi pula.

\section{Pembahasan}

Hasil pengujian hipotesis penelitian menunjukkan bahwa Website Quality berpengaruh terhadap Trust. Temuan ini bisa dijelaskan bahwa semakin tinggi kualitas sebuah situs web online shop, maka konsumen akan semakin mempercayai situs tersebut. Website Quality menggambarkan kapabilitas atau kemampuan online shop untuk bisa memberikan layanan yang maksimal atas kebutuhan konsumen. Setelah konsumen mengunjungi suatu online shop akan memunculkan berbagai penilaian di benak konsumen dan penilaian ini akan menentukan sejauh mana konsumen percaya kepada online shop tersebut. Trust berpengaruh terhadap loyalty artinya bahwa tinggi rendahnya kepercayaan konsumen terhadap layanan online shop mempengaruhi loyalitas konsumen dalam melakukan kunjungan ke sebuah online shop, kepercayaan yang tinggi menggambarkan rendahnya risiko secara psikologi dari dalam diri konsumen dan hal ini yang menyebabkan konsumen untuk tetap bertahan dan melakukan transaksi berulang pada satu online shop.

\section{KESIMPULAN DAN SARAN}

Kesimpulan dan saran dari penelitian ini berdasarkan pada hasil pengujian hipotesis penelitian adalah sebagai berikut:

1. Website Quality terbukti berpengaruh terhadap Trust. Tampilan yang informatif, kesan keamanan, 
kemudahan dalam pengoperasian, kenyamanan dalam penggunaan, serta kualitas layanan yang baik dari website mampu meningkatkan kepercayaan konsumen terhadap kapabilitas atau kompetensi online shop dalam memberikan layanan.

2. Trust yang tinggi dari konsumen mempengaruhi loyalty konsumen. Ketika konsumen memiliki kepercayaan yang tinggi maka konsumen cenderung untuk mempertahankan kunjungan dan pembelian pada satu online shop.

3. Pemilik online shop terus meningkatkan kualitas website yang dimiliki, seperti kemudahan mengakses, kemudahan mengoperasikan, terbebas dari hacker, dan contact person yang selalu bisa dihubungi. Dengan kualitas situs web yang lebih baik akan menimbulkan kepercayaan yang lebih tinggi dan pada akhirnya akan menghasilkan pelanggan yang loyal.

4. Pada penelitian selanjutnya, penentuan responden harus lebih diperhatikan, seperti contohnya responden memang benar-benar merupakan pelanggan online shop dan sudah terbiasa dengan berbelanja secara online

\section{DAFTAR PUSTAKA}

Buttner, O.B. \& Goritz, A.S. (2008, JanuaryFebruary). Perceived trustworthiness of online shops. Journal of Consumer Behaviour. 7, pp. 35-50.

Gregg, D.G. \& Walczak, S. (2010, March). The relationship between website quality, trust and price premiums at online auctions. Journal Electronic Commerce Research. 10(1), pp. 1-25.

Gutavsson, M. \& Johansson, A. (2006).Consumer Trust in E-Commerce.http://www.diva-portal. org/smash/get/diva2:230780/FULLTEXT01.pdf diakses pada 27 Oktober 2013.

Ganesan, S. (1994). Determinants of Longterm Orientation in Buyer-Seller Relationship, Journal Marketing. 58, pp. 1-19.
Gommans, M., Krishman, K. S., and Scheffold, K. B. (2001). From brand loyalty to e-loyalty: A conceptual framework. Journal of Economic \& Social Research, 3(1):43 - 58 .

Hur et al. (2011). A Structural Model of the Relationships Between Sport Website Quality, ESatisfaction, and E-Loyalty. Journal of Sport Management. 25, pp. 458-473.

Kheng, L.L. (2010, November). The Impact of Service Quality on Customer Loyalty: A Study of Banks in Penang, Malaysia. International Journal of Marketing Studies. 2(2).

Munusamy et al. (2010. October). Service Quality Delivery and Its Impact on Customer Satisfaction in the Banking Sector in Malaysia. International Journal of Innovation, Management and Technology. 1(4).

Pratiwi, H.D. (2012). Pengaruh Reputasi Perusahaan dan Kualitas Website Terhadap Tingkat Kepercayaan Konsumen Dalam Bertransaksi Secara Online (Studi pada Konsumen Ongisnadestore. com). http://www.academia.edu/3844914/ diakses pada 14 November 2013.

Sadeh et al. (2012).The Effects of Website Quality Dimensions on Customer Satisfaction in ERetailing System. Middle-East Journal of Scientific Research. 10(3), pp. 366-369.

Sekaran, U. (2006). Metodologi Penelitian untuk Bisnis. Edisi 4. Jakarta: Salemba Empat.

Schiffman, L.G. \& Kanuk, L.L. (2004). Consumer Behavior International Edition Eighth Edition. Pearson Prentice Hall: USA.

Sumarwan et al. (2007, Oktober).Analisis FaktorFaktor Yang Mempengaruhi Kepuasan Pelanggan Online. Jurnal Manajemen dan Agribisnis. 4(2), pp. 67-810.

Zhang, X. (2009, April-June). A Model of the Relationship among Consumer Trust, Web Design and User Attributes. Journal of Organizational and End User Computing, 21(2), 44-66. 